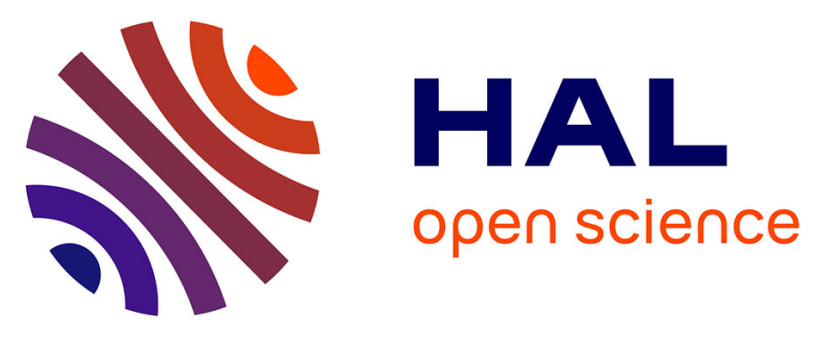

\title{
Integrative taxonomy of Meloidogye ottersoni (Thorne, 1969) Franklin, 1971 (Nematoda: Meloidogynidae) parasitizing flooded rice in Brazil
}

Raycenne Rosa Leite, Ana Cristina M. M. Gomes, Leandro Grimaldi Py, Vanessa S Mattos, Ana Cristina M M Gomes, Leandro Grimaldi Py, Daniela A Souza, Philippe Castagnone-Sereno, Juvenil E Cares, Regina M D G Carneiro

\section{To cite this version:}

Raycenne Rosa Leite, Ana Cristina M. M. Gomes, Leandro Grimaldi Py, Vanessa S Mattos, Ana Cristina M M Gomes, et al.. Integrative taxonomy of Meloidogye ottersoni (Thorne, 1969) Franklin, 1971 (Nematoda: Meloidogynidae) parasitizing flooded rice in Brazil. European Journal of Plant Pathology, 2020, 157 (4), pp.943-959. 10.1007/s10658-020-02049-y · hal-03285574

\section{HAL Id: hal-03285574 \\ https://hal.inrae.fr/hal-03285574}

Submitted on 13 Jul 2021

HAL is a multi-disciplinary open access archive for the deposit and dissemination of scientific research documents, whether they are published or not. The documents may come from teaching and research institutions in France or abroad, or from public or private research centers.
L'archive ouverte pluridisciplinaire HAL, est destinée au dépôt et à la diffusion de documents scientifiques de niveau recherche, publiés ou non, émanant des établissements d'enseignement et de recherche français ou étrangers, des laboratoires publics ou privés. 
Integrative taxonomy of Meloidogye ottersoni (Thorne, 1969) Franklin, 1971 (Nematoda: Meloidogynidae) parasitizing flooded rice in Brazil

Article in European Journal of Plant Pathology · July 2020

DOI: 10.1007/s10658-020-02049-y

\section{CITATION}

1

8 authors, including:

Raycenne Leite

University of Brasília

6 PUBLICATIONS 13 CITATIONS

SEE PROFILE

(6) Daniela Aguiar Souza

Empresa brasileira de pesquisa agropecuária, Embrapa

20 PUBLICATIONS 201 CITATIONS

SEE PROFILE
Vanessa Silva Mattos

Scientia Terrae Research Institute

29 PUBLICATIONS 184 CITATIONS

SEE PROFILE

Juvenil Cares

University of Brasília

45 PUBLICATIONS 562 CITATIONS

SEE PROFILE

Some of the authors of this publication are also working on these related projects:

NEMARACE - Genomic sequencing and polymorphism analysis of the different races of Meloidogyne incognita View project

Biological Control of Pests and Diseases with Bacteria and Fungi View project 


\title{
Integrative taxonomy of Meloidogye ottersoni (Thorne, 1969) Franklin, 1971 (Nematoda: Meloidogynidae) parasitizing flooded rice in Brazil
}

\author{
Raycenne Rosa Leite • Vanessa S. Mattos • Ana Cristina M. M. Gomes • Leandro \\ Grimaldi Py • Daniela A. Souza • Philippe Castagnone-Sereno • Juvenil E. Cares • Regina \\ M. D. G. Carneiro $(\mathbb{D}$
}

\begin{abstract}
A root-knot nematode (RKN) parasitizing rice (Oryza sativa L.) and causing damage in Santa Catarina (SC), Rio Grande do Sul (RS) and Paraná (PR) states (Brazil) was identified as Meloidogyne ottersoni (Thorne 1969) Franklin 1971. The species is redescribed from the Brazilian population from Meleiro (SC) and compared with the description of M. ottersoni from Wind Lake (Wisconsin, USA) with additional morphological, biochemical and molecular characterization. The female and male bear smaller stylets: 10-12 $\mu \mathrm{m}, 14-16 \mu \mathrm{m}$, respectively, when compared with M. graminicola: $12-14 \mu \mathrm{m}, 16-18 \mu \mathrm{m}$, and M. oryzae: 14-16 $\mu \mathrm{m}, 18-20 \mu \mathrm{m}$. Meloidogyne ottersoni presents perineal patterns located on the contour of a slight
\end{abstract}

Raycenne Rosa Leite and Vanessa S. Mattos contributed equally to this work.

R. R. Leite · J. E. Cares

Departamento de Fitopatologia, Universidade de Brasília, Brasília, DF 70910-900, Brazil

R. R. Leite · V. S. Mattos · A. C. M. M. Gomes •

D. A. Souza · R. M. D. G. Carneiro $(\bowtie)$

Embrapa Recursos Genéticos e Biotecnologia, Brasília, DF 70770901, Brazil

e-mail: regina.carneiro@embrapa.br

L. G. Py

Rua Frei Humberto Weil, 29, Bairro Perequê, Porto Belo, SC 88210-000, Brazil

P. Castagnone-Sereno

INRAE, CNRS, ISA, Université Nice Côte d'Azur, F-06903

Sophia Antipolis, Nice, France protuberance. Striae are mostly continuous, never raised by transverse irregular striae, as frequently observed in M. graminicola and M. oryzae. Meloidogyne ottersoni belongs to the RKN group 11 described by Jepson (1987); the reproduction is by meiotic parthenogenesis and the somatic chromosome number is 18 . The tail of second-stage juveniles is very long and thin, and tapers to a long, narrow, irregular hyaline terminus (M. ottersoni, $20.5 \mu \mathrm{m}$ vs M. graminicola, $17.9 \mu \mathrm{m}$ and $M$. oryzae, $22.0 \mu \mathrm{m}$, respectively). The ability of the Brazilian M. ottersoni population to parasitize canary grass, Phalaris arundinacea L. (type host), and barnyard grass, Echinocloa crus-galli, was confirmed. Biochemically, the esterase profile of $M$. ottersoni lacks any band (Est Ot0, Rm=0), which differentiates it from M. graminicola and M. oryzae (Est VS1, $\mathrm{Rm}=0.70$ and Est O1, Rm=1.02, respectively). In Maximum Likelihood analysis of ITS, D2D3 and COXII-16S rRNA sequences, populations of $M$. ottersoni from different states of Brazil clustered together and were separated from other Meloidogyne spp., thus confirming that all four populations are very similar and conspecific.

Keywords COXII · D2D3 - esterase phenotyping · ITS · morphology $\cdot$ Oryza $\cdot$ root-knot nematode

\section{Introduction}

Rice (Oryza sativa L.) is the third most produced cereal worldwide, just after maize and wheat, and plays a key 
role in the current and future food security across the globe. Outside Asia, Brazil is the largest rice-producing country (Chauhan et al. 2017), the Southern Brazilian states being responsible for more than $80 \%$ of all national production, with the predominance of flooded rice (Conab 2018).

Several factors can interfere in rice crop yield, including nematodes. Nematodes from more than 35 genera have been reported parasitizing rice plants, but few species are described causing significant damage (Khan 2015). In particular, the flooded rice system determines the community of plant parasitic nematodes by selecting the most adapted ones, and several authors have reported the predominance of M. graminicola Golden and Birchfield, 1965 in this cropping system (De Waele and Elsen 2007; Khan 2015).

All the populations in the Meloidogyne species complex detected on rice in Brazil (Mattos et al. 2017) belong to the 'graminis group', which includes some species with similar characteristics: females deeply embedded in the host and body elongate with different forms, vulva situated on posterior protuberance, second-stage juveniles with hyaline part of the tail very thin and long, meiotic parthenogenesis as the mode of reproduction, males common (Jepson 1987).

A recent survey in Brazil detected M. graminicola and other atypical esterase phenotype populations of Meloidogyne spp. in flooded rice fields of Rio Grande do Sul (RS), Santa Catarina (SC) and Paraná (PR) states, causing damage under field conditions (Negretti et al. 2017; Mattos et al. 2018). In these studies, enzymatic and molecular analysis revealed the existence of a 'species complex' parasitizing rice in the Southern region of Brazil. In the survey conducted by Negretti et al. (2017), a particular population provisionally named Meloidogyne sp.0, lacking any band in its esterase profile, was not detected, probably due to this biochemical character. Subsequently, the same population was detected in four different municipalities in three Brazilian southern states: Capão do Leão (RS), Meleiro (SC), Nova Veneza (SC) and Santa Cruz de Monte Castelo (PR) (Mattos et al. 2017). At the same time, a new root-knot nematode parasitizing rice in SC was identified as Meloidogyne oryzae Maas, Sanders and Dede, 1978. This species was re-described from this Brazilian population and compared with the type description of $M$. oryzae from Suriname, with additional morphological, biochemical and molecular characterization (Mattos et al. 2018).
The identification of Meloidogyne species is not an easy task, considering the large number of species belonging to the genus, their worldwide distribution and their wide host range. The morphological similarity between species is also a factor that makes identification difficult, since inter and intra-specific differences are very subtle (Jepson 1987; Karssen and Moens 2006; Moens et al. 2009). Alternatively, molecular methods have been used successfully to identify Meloidogyne species. In particular, for M. graminicola, sequences of nuclear ribosomal (rDNA) and mitochondrial DNA (mtDNA) have been largely applied (Pokharel et al. 2007, 2010; Bellafiore et al. 2015; McClure et al. 2012; Htay et al. 2016). Recently, two diagnostic SCAR markers were proposed for this species (Bellafiore et al. 2015; Mattos et al. 2018) and also for M. oryzae and M. salasi Lopez, 1984 (Mattos et al. 2018).

The populations presenting esterase phenotype without any band (i.e., corresponding to the unknown species Meloidogyne sp.0) were detected as pure populations on rice in field conditions, predominantly in the SC state and less frequently in the PR and RS states (Mattos et al. 2017). Therefore, the aim of this study was to identify and characterize this unknown Meloidogyne sp.0 using an integrative taxonomy approach. Based on morphological, morphometrical and molecular differences with other Meloidogyne species from the 'graminis group', we assign Meloidogyne sp.0 to the species Meloidogyne ottersoni (Thorne 1969) Franklin 1971, and we report its first occurrence on rice in the Southern region of Brazil.

\section{Materials and Methods}

Populations of nematodes

Four pure RKN populations exhibiting an esterase phenotype with no band (i.e., Meloidogyne sp. $0, \mathrm{Rm}=0$ ) were sampled in fields from RS and SC states and multiplied on rice plants $O$. sativa (IRGA-410 and IRGA-424), in greenhouse conditions, with an average temperature of $15-28^{\circ} \mathrm{C}$. All biochemical and molecular studies were done using these four pure cultures (Table 1). Morphological and cytogenetic studies were performed with one population from Meleiro, SC. Egg masses and females were obtained directly from the infected rice roots. Second-stage juveniles (J2) were hatched in humid chambers. Males were obtained by 
Table 1 List of Meloidogyne ottersoni isolates studied in this paper

\begin{tabular}{|c|c|c|c|c|c|c|}
\hline \multirow[t]{2}{*}{$\operatorname{Code}^{\mathrm{a}}$} & \multirow[t]{2}{*}{ Species } & \multirow{2}{*}{$\begin{array}{l}\text { Origin } \\
\text { Municipality-State }^{\mathrm{b}}\end{array}$} & \multirow{2}{*}{$\begin{array}{l}\text { Isozyme } \\
\text { phenotypes } \\
(\text { Est) }\end{array}$} & \multicolumn{3}{|c|}{ GenBank accession number ${ }^{\mathrm{d}}$} \\
\hline & & & & ITS & D2D3 & mtDNA \\
\hline Ot1 & M. ottersoni & Capão do Leão-RS & Ot0 & MN563096 & MN578129 & MN585719 \\
\hline Ot 2 & M. ottersoni & Nova Veneza-SC & Ot0 & MN563095 & MN578130 & MN585718 \\
\hline Ot 3 & M. ottersoni & Nova Veneza-SC & Ot0 & MN563094 & MN578131 & MN585717 \\
\hline Ot $4 *$ & M. ottersoni & Meleiro-SC & Ot0 & MN563093 & MN578132 & MN585716 \\
\hline
\end{tabular}

${ }^{\text {a }}$ Population code used in the study

${ }^{\mathrm{b}}$ Brazilian states: $\mathrm{RS}=\mathrm{Rio}$ Grande do Sul and $\mathrm{SC}=$ Santa Catarina

${ }^{\mathrm{c}}$ Est: esterase phenotype

${ }^{\mathrm{d}}$ GenBank accession numbers for the D2-D3 fragment of 28S rRNA, ITS1-5.8S-ITS2 rRNA, COII mtDNA cloned in our laboratory and used for alignment and phylogenetic analysis

*Population used in the morphological and cytogenetic studies

placing the infected rice roots in aerated water using an aquarium pump. The specimens were collected periodically from the water (every $24 \mathrm{~h}$ for $\mathrm{J} 2$ and $48 \mathrm{~h}$ for males, respectively) (Carneiro et al. 1998).

\section{Morphological and morphometric studies}

Morphological and morphometric studies were performed with at least 30 specimens from each developmental stage. Males and J2 were killed in cold 2\% formaldehyde $\left(5^{\circ} \mathrm{C}\right)$, measured and photographed immediately under a light microscope. Morphometric studies were performed using the measurements suggested by Eisenback and Hunt (2009). The biometric studies were performed with adult females, cut in $45 \%$ lactic acid and their anterior region mounted with $2 \%$ formaldehyde at room temperature. The perineal cuts were mounted in glycerin (Taylor and Netscher 1974). The micrographs and measurements were performed in a Zeiss - Axiophot Microscope under white light. Females, males, J2 and stylets (from females and males) were prepared for scanning electron microscopy (SEM) according to the methods proposed by Eisenback (1985). Specimens were viewed and photographed with a scanning electron microscope JEOL-JSM-7001F.

Biochemical and cytogenetic studies

The biochemical characterization of the four RKN populations was performed on $7 \%$ polyacrylamide gel slab isozymes in a horizontal electrophoresis system, according to Carneiro and Almeida (2001). Meloidogyne javanica (Treub, 1885) Chitwood, 1949 (EST J3, MDH N1) was used as reference. Both esterase (EST) and malate dehydrogenase (MDH) enzymes were investigated. Cytogenetic studies were carried out using a propionic orcein staining method (Triantaphyllou 1985).

\section{Type Host Test}

In order to verify the host response of reed canary grass (Phalaris arundinacea L.), to Meloidogyne sp. 0, seeds of this plant obtained from Cobase Cenargen, Embrapa were germinated in 31 pots. Seedlings $5-\mathrm{cm}$ long were inoculated with 5,000 eggs of Meloidogyne sp. 0 and kept in a greenhouse at an average temperature between 15 and $25^{\circ} \mathrm{C}$, with watering and fertilization as needed. Fifty days after inoculation (DAI), the roots were washed thoroughly with tap water, then stained with acid fuchsin (Byrd et al. 1983) and observed under a stereoscopic microscope to document the J2 penetration and the development of females and egg laying within the roots.

\section{Host status of other plants}

In order to verify the reproduction of Meloidogyne sp.0 in other plants: corn, wheat, pearl millet, signalgrass, cowpea, white oat, black oat, barley, Italian ryegrass, soybean, guinea grass, barnyard grass, jungle rice, canary grass, tomato and the rice cultivar IRGA 424 (positive check) were used in the host test (Table 3); 
the seeds were germinated in trays and when they were $5-10 \mathrm{~cm}$ long, they were transplanted to 3-1 pots. All plants (eight/treatment) were inoculated with 10,000 eggs/plant of Meloidogyne sp.0 and kept in a greenhouse for two/three months, at an average temperature of 25 and $30{ }^{\circ} \mathrm{C}$, with watering and fertilization as needed. After the nematode multiplication period (2-3 months), the plants were evaluated by the reproduction factor (RF), which was calculated by the equation: $R F=$ final nematode population / initial nematode population 5,000 eggs/plant). Eggs were extracted by the method described by Hussey and Barker (1973), using a blender instead of manual shaking for 30 seconds, and counted on Peter's slides.

Phylogenetic analyses

For the phylogenetic analyses, three DNA sequences from the four populations of Meloidogyne sp.0 from rice, originating from Brazil (Table 1) were amplified by the ITS1-5.8S-ITS2 region of rRNA (primer set: forward 5'-TTGATTACGTCCCTGCCCTTT-3' and reverse 5'-TCCTCCGCTAAATGATATG-3'; Schmitz et al. 1998); the D2-D3 fragment of the 28S rRNA gene (primer set: forward 5'-ACAAAGTACCGTGA GGGAAAGTTG-3' and reverse 5'-TCGGAAGG AACCAGCTACTA-3'; De Ley et al. 1999); and the $3^{\prime}$ portion of COXII and the $5^{\prime}$ portion of $16 \mathrm{~S}$ rRNA mitochondrial region (primer set: forward 5'GGTCAATGTTCAGAAATTTGTGG-3' and reverse 5'-TACCTTTGACCAATCACGCT-3'; Powers and Harris 1993), using the PCR conditions described by Subbotin et al. (2000). PCR products were cleaned using the Wizard® SV Gel/PCR Clean Up System (Promega) and cloned into the pGem-T® Easy Vector (Promega), following the manufacturer's instructions. Sequencing of the insert was carried out on two independent clones by Macrogen.

Cloned sequences were aligned using ClustalW in Mega 5.0.3 (Tamura et al. 2011) and compared with other retrieved sequences from the NCBI database. The program MrModeltest (Nylander 2004) implemented in PAUP (Phylogenetic Analysis Using Parsimony; v.4.0 b10) was used to identify the best-fit models of each analysis. The phylogenetic trees were generated based on Maximum Likelihood (ML) analysis in IQtree (Trifinopoulos et al. 2016). The phylogram was bootstrapped 1,000 times, and only support values above $50 \%$ were considered.

\section{Results}

Symptoms on rice and on reed canary grass

Meloidogyne sp.0 infection on rice forms an arcuate, elongated gall and then proceeds to develop a series of similar galls containing some females completely embedded in the root tissue where the eggs are laid. The egg-masses are internal or external. Males are very frequent and they are often found inside the root with females and second-stage juveniles. The population from Meleiro reproduced also on reed canary grass, Phalaris arundinacea (type host) exhibiting the same rice symptoms, $\mathrm{J} 2$ present within the roots, and females with egg masses, 50 days after inoculation (Fig. 9) and the Reproduction Factor $(\mathrm{RF})=6.23$.

Morphological and morphometric studies

Females Measurements of 30 females are shown in Table 2. The body is variable in shape and size (410$960,668.9 \mu \mathrm{m})$, general oval to pear shaped or elongate, translucent-white, neck variable $(78-118 \mu \mathrm{m}, 92.2 \mu \mathrm{m})$ projecting at different angles, vulval and anal region usually with slight protuberance (Fig.1 a, b), but sometimes this elevation is not present. Perineal patterns rounded/oval dorsoventrally with mostly continuous striae and without marked lateral lines (Fig. 1 a-f), striae coarse, dorsal arch low and rounded. Perivulval region usually free of striae and no striae above the anus. No punctuations observed. Tail terminus and lateral fields not clearly defined and phasmids distinct. Ventral region rounded. Excretory pore located two stylet lengths or less below head end (Fig. 2 a, f). In SEM (Fig. 2 b, c) labial disc fused with medial lips forming a continuous labial cap. Lateral lips distinct, triangular. Amphid apertures slightly oval, located at apices of lateral lips, sometimes continuous with the first annulus clearly demarcated (Fig. 2 b, c). Stylet robust $(9-13,11.4$ ) $\mu \mathrm{m})$, cone straight or slightly curved dorsally and gradually increasing in diameter posteriorly. Shaft gradually widening posteriorly to near junction with stylet knobs, knobs rounded and set off from the shaft (Fig. 2 c, d). Dorsal gland orifice (DGO) 3-6 $\mu \mathrm{m}(4.4 \mu \mathrm{m})$ from the base of stylet.

Males Measurements of 30 males are shown in Table 2. Body vermiform, variable in size $(760-1,430 \mu \mathrm{m}$, $1188.6 \mu \mathrm{m}$ ) tapering anteriorly, tail variable in form, 
Table 2 Morphometric data of females, males and second-stage juveniles (J2) of Meloidogyne ottersoni from Brazil

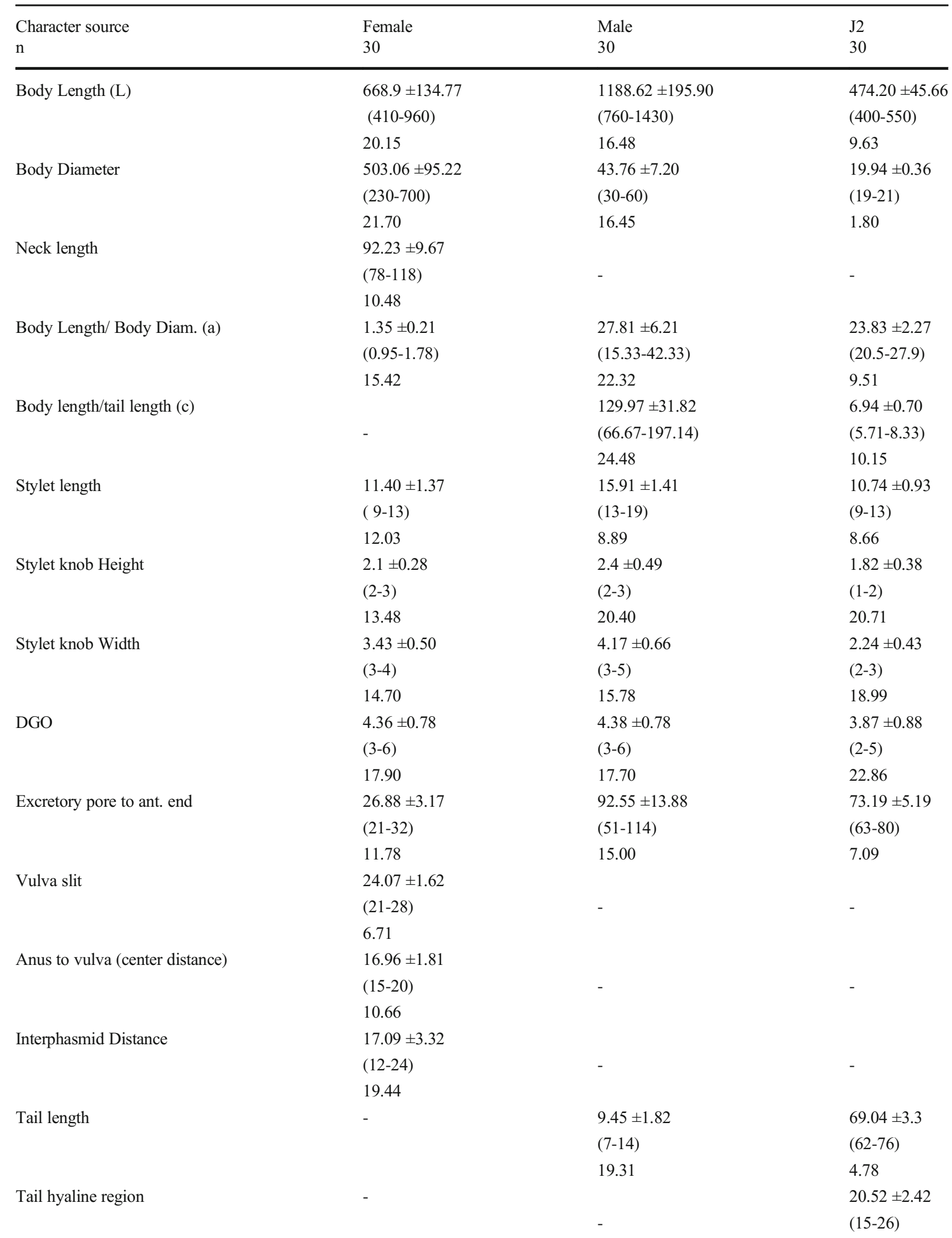


Table 2 (continued)

\begin{tabular}{llll}
\hline Character source & Female & Male & J2 \\
$\mathrm{n}$ & 30 & 30 & 30 \\
\hline & & & 11.79 \\
Spicule length & - & $25.41 \pm 3.94$ & - \\
& & $(16-30)$ & 15.52 \\
Gubernaculum & - & $7.1 \pm 1.0$ & - \\
& & $(5-9)$ & 14.03 \\
\hline
\end{tabular}

All measurements are $\mu \mathrm{m}$ and in the form: mean \pm s.d. (range) and coefficient of variation

sometimes with an expansion (Fig. 3 f), usually twisting $90^{\circ}$. Cuticular annulations coarse (Fig. 3 a-c). Head cap high, rounded, dome shaped; head region distinct from the first body annulus, without (Fig 3 a, d) or with some weak annulations (Fig. 3 b, c) under SEM. Labial disc and medial lips fused forming a smooth, continuous head cap (Fig. 3 a-d). Labial disc slightly elevated above medial lips. Lateral lips demarcated or not on the head region (Fig. 3 a-d). Amphid apertures forming elongate slits (Fig. 3 a-d). Stylet robust (13-19 $\mu \mathrm{m}, 15.9 \mu \mathrm{m})$, cone pointed at the tip, widening at junction with shaft, shaft cylindrical. Knobs round to oval-shaped sloping backward (Fig. 3 h, i). Excretory canal prominent, twisting irregularly, visible to the end of gland lobe. DGO 3-6 $\mu \mathrm{m}$ from stylet base. Lateral fields variable composed of different forms and numbers of incisures (4-7). Spicules and gubernaculum arcuate, phasmids almost terminal.

Second-stage juveniles (J2) Measurements of $30 \mathrm{~J} 2$ are given in Table 2 . Body cylindrical vermiform tapering to an elongated tail. Head with slight cephalic frameworks not offset from the body without postlabial annuli (Fig. 4 a, b). Stylet delicate $(9-13 \mu \mathrm{m}, 10.7 \mu \mathrm{m})$, knobs rounded tapering onto shaft. Ampula obscure. Dorsal gland orifice to stylet base $(2-5 \mu \mathrm{m}, 3.9 \mu \mathrm{m})$. Metacorpus broadly oval, valve large and heavily sclerotized (Fig. 4 c). Excretory pore below nerve ring. Anal opening obscure. In SEM, labial disc and medial lips fused forming a smooth, continuous head cap, bow-tie shaped. Six depressed sensila surrounded pre-stoma (Fig. 4 a, b). Amphid apertures large and slit-like. Lateral lips elongated (Fig. 4a, b). Excretory pore immediately posterior to hemizonid. Variable lateral fields usually with 4 incisures. Rectum not inflated. Tail elongated conoid $(62-76 \mu \mathrm{m}, 69.2 \mu \mathrm{m})$. Hyaline region of tail long, usually without regular annulation (15-25 $\mu \mathrm{m}$, $20.5 \mu \mathrm{m}$ ), constricting at one, two or three places, tapering to a slender, terminal digitiform tip (Fig. 4 e-i).

Biochemical and cytological studies

The enzymatic analyses revealed the lack of any esterase band $(\mathrm{Rm}=0)$ for the four populations of Meloidogyne sp.0. This observation was strengthened by using more than 20 macerated females as substrate in each individual analysis (Fig. 5). For the enzyme Mdh, the obtained phenotype is N1a (Rm: 1.4), the same as in the species M. graminicola, M. oryzae and M. naasi (Esbenshade and Triantaphyllou 1985). The reproduction of Meloidogyne sp.0 is by meiotic parthenogenesis and the somatic chromosome number is 18 .

\section{Molecular analysis}

Phylogenetic analyses were further conducted to validate the results obtained with morphological approaches and isozymes, comparing sequences of the ITS1-5.8SITS2 rRNA segment, the D2-D3 fragment of 28S rRNA, and the partial mitochondrial region between the COXII and the 16S rRNA genes of Meloidogyne sp.0 populations to homologous sequences from other Meloidogyne spp. obtained from GenBank. The individual ML trees obtained for all sequences were similar, and showed that the four isolates of Meloidogyne sp.0 from Brazil were distributed into a single cluster (99-100\% bootstrap values), as shown in Figs. 6, 7 and 8, thus strongly suggesting that they belong to the same species. 
Fig. 1 Meloidogyne ottersoni perineal patterns. a, b: Scanning electron microscopy micrographs (SEM); c-f: light microscopy micrographs. Arrows showing slight protuberance of vulval region
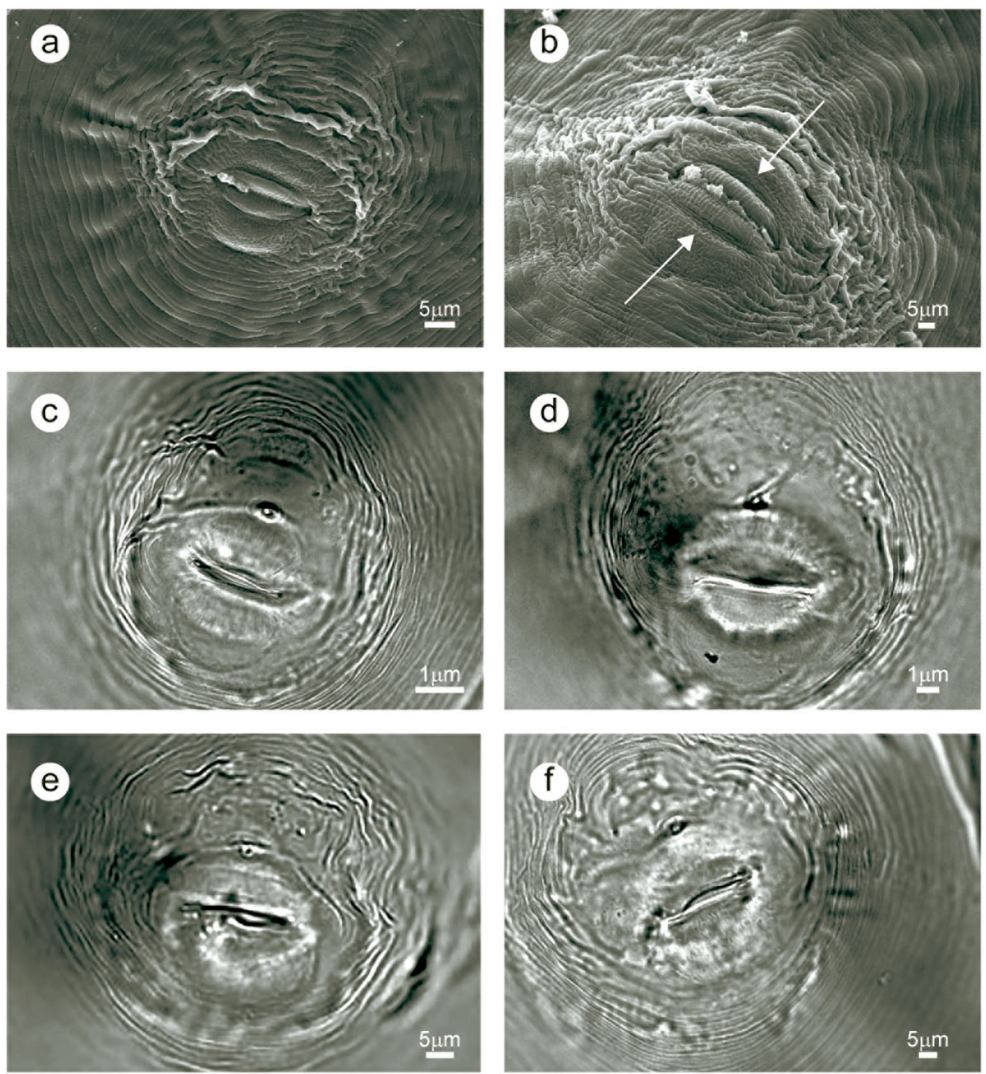

Intraspecific variability among the four populations of Meloidogyne sp.0, between 1 and 4 nucleotides (in a total of 755 nucleotides) for ITS sequences and about 11-16 nucleotides (in 743 nucleotides) for D2D3. Population from RS (Ot1) seems to be genetically different from the others from SC (Ot2, Ot3 and Ot4). The coxII16S rRNA region of Meloidogyne sp.0 populations also showed a low intraspecific variability; i.e., 1-2 nucleotides in 522. However, this region contains a variable intergenic sequence which clearly separates Meloidogyne sp.0 populations from other $\mathrm{RKN}$ ricerelated species.

Meloidogyne sp. 0 is closely related to meiotic species like M. graminicola, M. salasi, M. naasi Franklin, 1965, M. trifoliophila Bernard and Eisenback 1997 and other species belonging to Jepson's group 11. Contrarily,
M. incognita, M. javanica, M. minor Karssen, Bolk, van Aelst, van den Beld, Kox, Korthals, Molendijk, Zijlstra, van Hoof and Cook, 2004 are genetically distant from this species, as demonstrated in our ML trees. Meloidogyne oryzae was closely related to Meloidogyne sp. 0 in the D2D3 and COXII ML trees. However, in the ITS analysis, this species appeared close to mitotic obligatory parthenogenetic species such as M. incognita and M. javanica (Fig. 6).

Diagnosis and Relationships

Based on the results obtained here, we concluded that the four Meloidogyne sp.0 populations from Brazil characterized in this study do indeed belong to the RKN species M. ottersoni (Thorne 1969) Franklin 1971. The 
Fig. 2 Meloidogyne ottersoni females. a-e: Scanning electron microscopy (SEM) micrographs of anterior region (a-c) and stylets (d, e). Light microscopy (LM) micrograph of anterior region (f). Arrow showing excretory pore of female
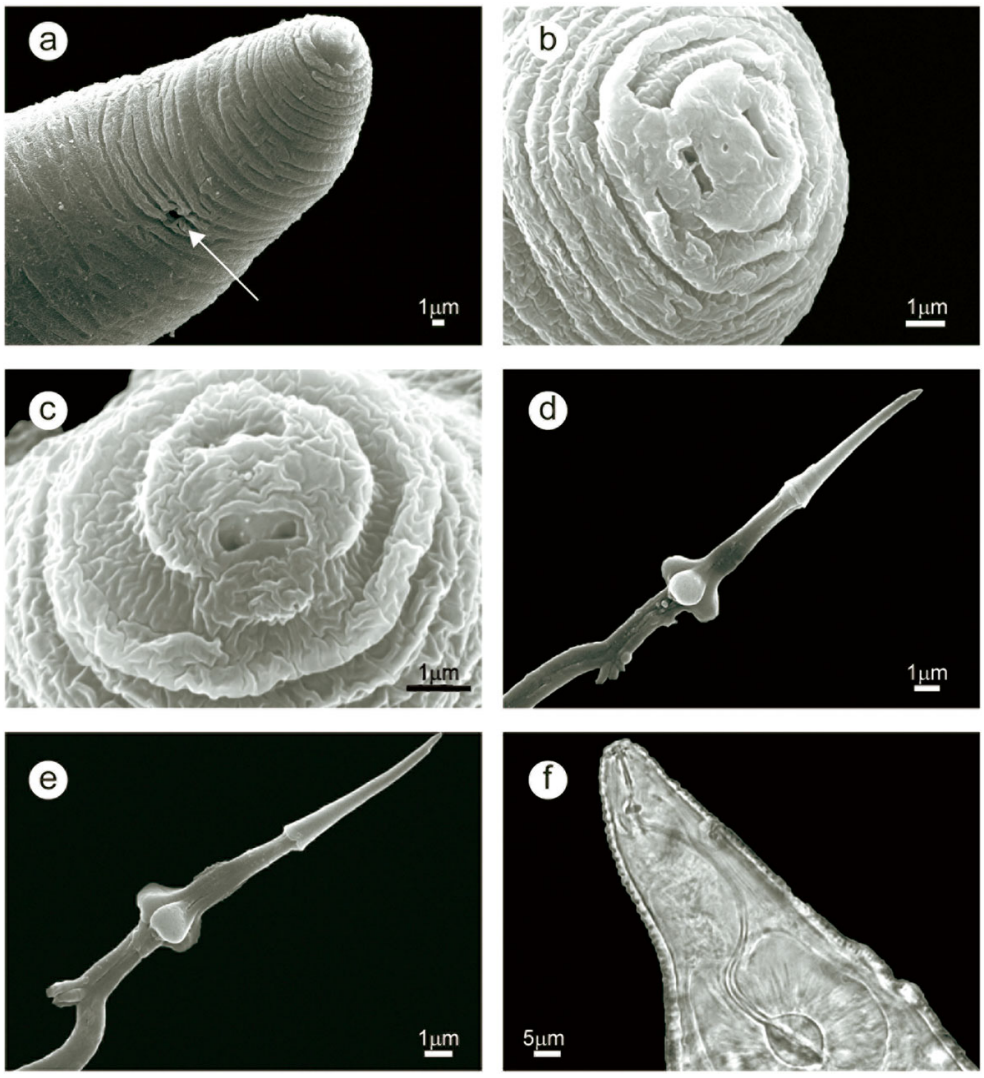

correct identification of $M$. ottersoni requires a detailed study of distinctive morphological features of the females, males and J2. Unfortunately, the type material was not available (Jepson 1987), and nor were live populations in US collections (Jonathan D. Eisenback and Zafar Handoo, personal information). Comparing the populations from Brazil with the description made by Thorne (1969) and Jepson (1987), it was possible to see that they present similar morphological and morphometrical features, as well as the following common characters described for the population of M. ottersoni from Wisconsin, USA. Females elongate, lemon shaped to nearly rounded. Perineal patterns located on the contour of the protuberance, rounded to oval; dorsal arch hemispherical with slightly spaced striae. Striae mostly continuous (Fig. 1), never raised by transverse irregular striae frequently observed in M. graminicola and M. oryzae. Quantitative differences between species belonging to the Jepson group 11 are reduced, but $M$. ottersoni shows a small female stylet (9$12 \mu \mathrm{m}$ ), different from other species: M. graminicola, 12-14 $\mu \mathrm{m}$ and M. oryzae, 14-16 $\mu \mathrm{m}$ (Jepson 1987; Mattos et al. 2018). The stylet knobs can also differentiate these three species: large transverse elongate knobs in M. graminicola (Eisenback and Triantaphyllou 1991), set off from the shaft in M. ottersoni and sloping backward in M. oryzae (Mattos et al. 2018). However, considering the size of cone in relation to shaft, it is bigger in M. graminicola, smaller in M. oryzae and the same size or bigger in M. ottersoni (Jepson 1987; Eisenback and Triantaphyllou 1991; Mattos et al. 2018). The length range of male stylets is also different among the three species: 13-19 $\mu \mathrm{m}$ for $M$. ottersoni, 16-18 $\mu \mathrm{m}$ for M. graminicola and 18-20 $\mu \mathrm{m}$ for M. oryzae (Jepson 1987). The tail of J2 of the three species is very long and thin and tapers to a long, narrow irregular hyaline terminus (M. ottersoni, $20.5 \mu \mathrm{m}, M$. graminicola, $17.9 \mu \mathrm{m}$ and $M$. oryzae, $22.0 \mu \mathrm{m}$ ), ending in a slightly clavate tip (Fig. 4 e-i). Populations of M. ottersoni show esterase phenotype without bands or enzymatic activity $(\mathrm{Rm}=0$, Est Ot0), completely different from $M$. graminicola (Est VS1) and M. oryzae (Est O1) with a very large drawnout area of enzymatic activity (Mattos et al. 2018). The esterase phenotype is therefore a great tool for identifying M. ottersoni (Est Ot0) from other species of parasites 

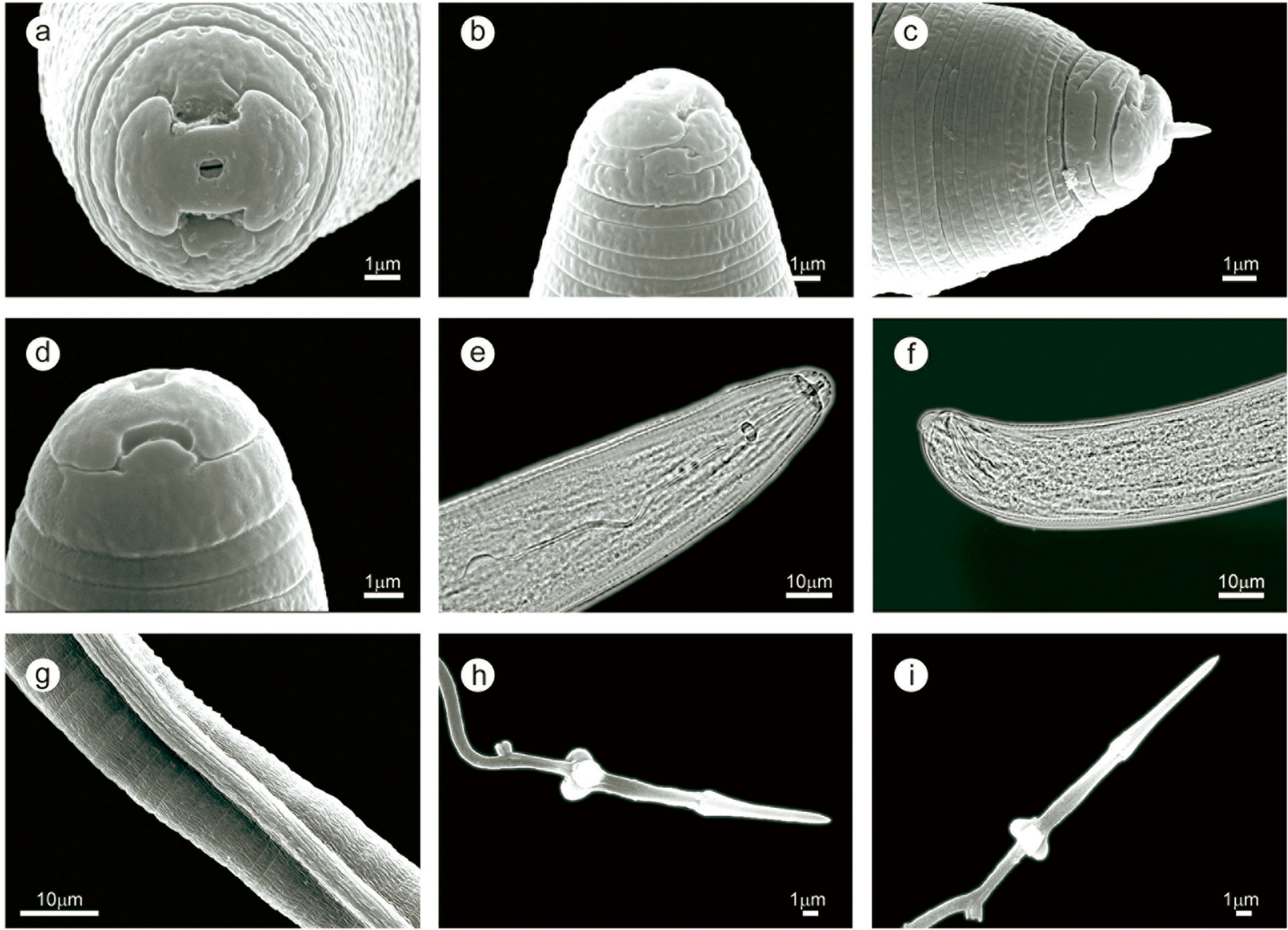

Fig. 3 Meloidogyne ottersoni males. a-d: Scanning electron microscopy (SEM) micrographs of anterior region. e, f: Light microscopy (LM) micrographs of anterior region (e) end tail (f). g: SEM of lateral fields; h, i: SEM of excised stylets

of rice (Fig. 5). Considering now the SCAR markers developed by Belafiore et al. (2015), Htay et al. (2016) and Mattos et al. (2018), unfortunately, they were not species-specific for M. graminicola, since they also amplify some populations of $M$. ottersoni. Nonetheless, M. ottersoni has specific ITS, D2-D3 and partial COXII16S rRNA sequences (Figs. 6, 7, 8). Meloidogyne ottersoni from rice also reproduced on the type host plant, reed canary grass, Phalaris arundinacea, showing $\mathrm{J} 2$ within the roots and females with egg masses, 50 days after inoculation (Fig. 9) and the Reproduction Factor $(\mathrm{RF})=6.23$, confirming the Koch's postulate.

\section{Host status of other plants}

Fifteen plants of different botanical species of local occurrence or with a potential to be used in crop rotation were analyzed for host suitability to $M$. ottersoni. Most of the plants were non-hosts or poor hosts (Table 3). In addition to Oryza sativa and the type host plant Phalaris arundinacea, only three plants were considered good hosts: Echinocloa crus-galli, Echinocloa colonum and Phalaris canariensis.

\section{Discussion}

The traditional identification methods of RKN are based on morphology (Jepson 1987; Eisenback and Triantaphyllou 1991; Hunt and Handoo 2009), esterase phenotypes (Esbenshade and Triantaphyllou 1985; Carneiro et al. 2000) and molecular markers (Blok and Powers 2009). The identification of Meloidogyne spp. from rice (group 11) has been a challenge with conservative morphology, unclear species boundaries and complex taxonomy (Jepson 1987), and a lack of SCAR markers for several species (Belafiore et al., 2015; Mattos et al. 2018) complicates the diagnosis. 

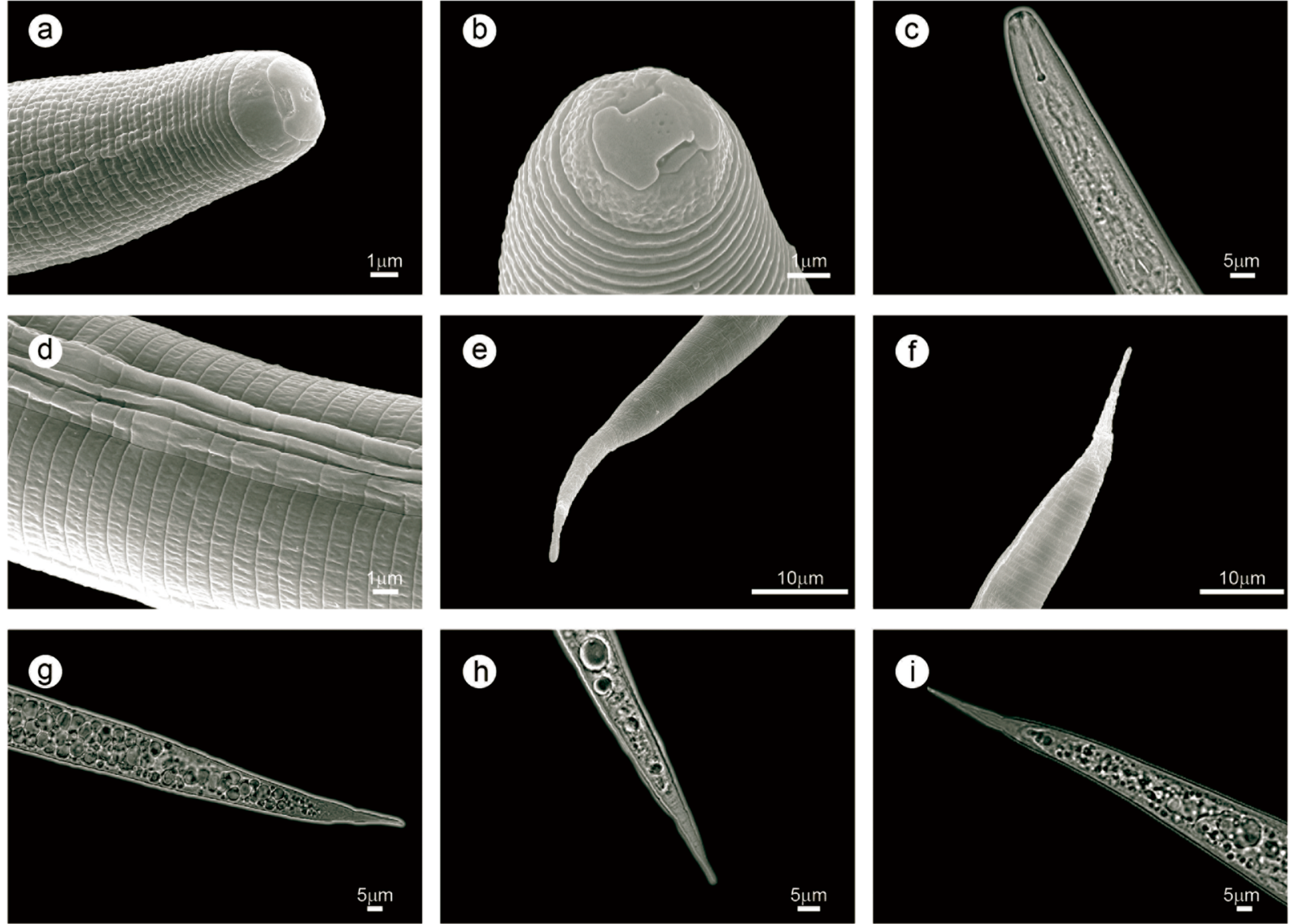

Fig. 4 Meloidogyne ottersoni, second-stage juveniles. a, b: Scanning electron microscopy (SEM) micrographs of anterior region. c: Light microscopy (LM) micrographs of anterior region; $\mathbf{d}$ : SEM of lateral fields; $\mathbf{e}, \mathbf{f}$ : SEM of tails in lateral and ventral views, $\mathbf{g}$-i: LM of tails in ventral and lateral views

The RKN species found on rice have been generally classified as M. graminicola, based largely on morphometric characters, the symptoms and the ability of this species to cause infection in lowland rice
Fig. 5 Esterase (a) and malate dehydrogenase (b) phenotypes of Meloidogyne ottersoni (Ot0,

N1A). Meloidogyne javanica (J3, N1) was used as reference

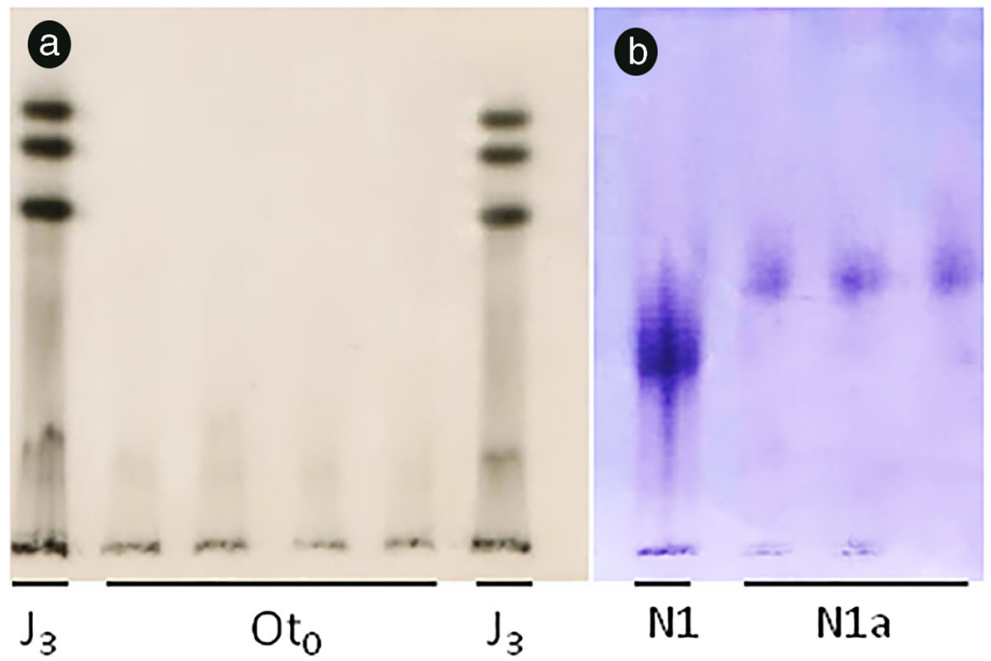



analysis of the phylogenetic relationships of Meloidogyne ottersoni (M. sp.0) and other Meloidogyne spp. populations based on the ITS1-5.8S-ITS2 rRNA sequences. Numbers to the left of the branches are bootstrap values for 1,000 replications. Accession numbers from GenBank are listed before the species names
Fig. 6 Maximum Likelihood

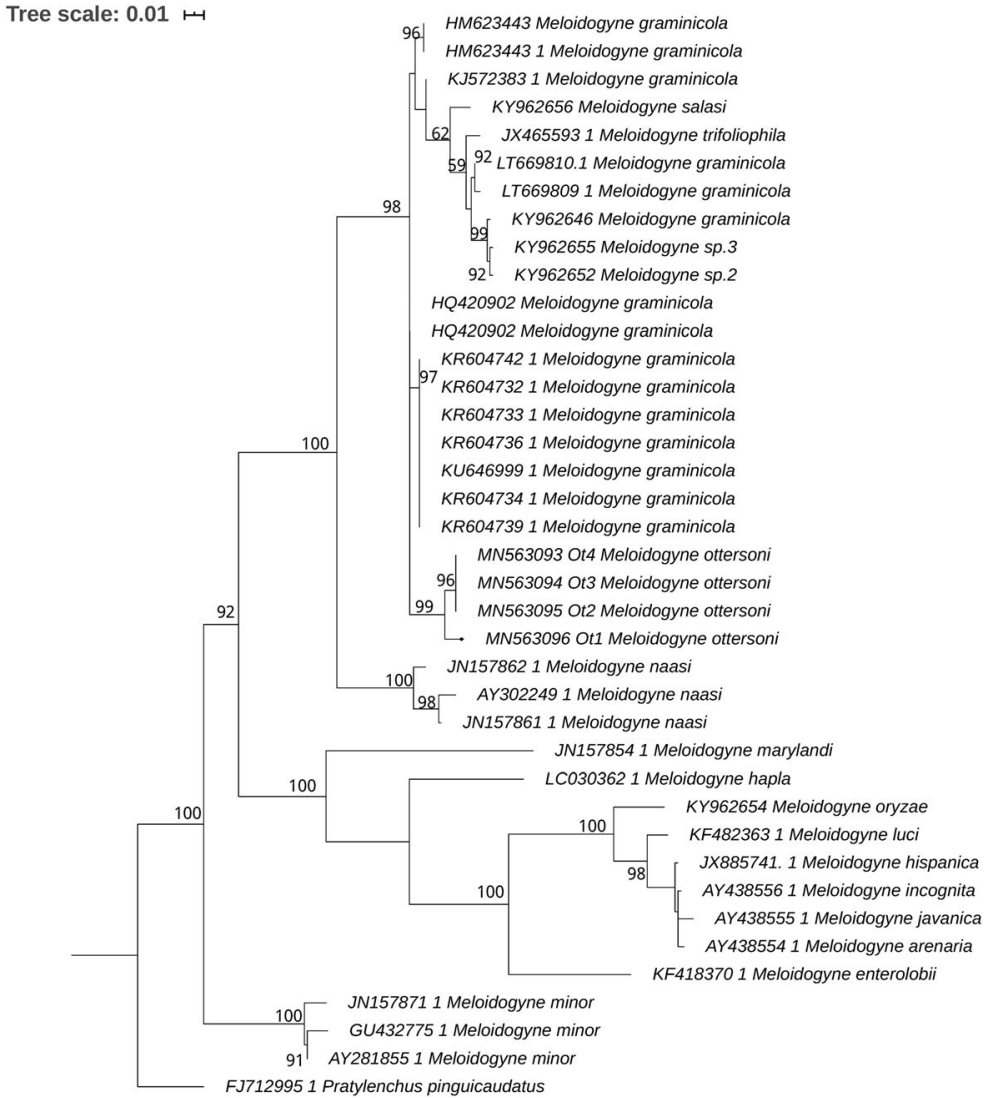

(Pokharel et al. 2007). However, detailed information on identity and variability of observed RKN is still lacking. Identification and diagnosis of $M$. graminicola has always been a challenge. Recently, Salalia et al. (2017), studying 14 populations belonging to the ' $M$. graminicola group' from India, suggested that cryptic species may be occurring mixed with the rice RKN. In a recent survey in southern Brazil, 21 populations of Meloidogyne spp. were detected in SC State. Meloidogyne sp.0, now identified as M. ottersoni, occurred in $19 \%$ of the samples, always by itself without mixtures with other species (Mattos et al. 2017). Meloidogyne graminicola was the most widespread nematode detected in the southern region of Brazil (Negretti et al. 2017).

Meloidogyne ottersoni from Wind Lake, Wisconsin, USA is a species well adapted to flood conditions and reproduces well on reed canary grass, Phalaris arundinacea. This plant is a perennial bunchgrass that commonly forms extensive single-species stands along the margins of lakes and streams and in wet open areas, with a wide distribution in Europe, Asia, northern Africa and North America.
In Brazil, M. ottersoni (=Meloidogyne sp.0) was detected in rice regions in flooded soil, with low drainage capacity. The average temperature in this region is $19.5^{\circ} \mathrm{C}$, ranging from $10{ }^{\circ} \mathrm{C}$ to $25^{\circ} \mathrm{C}$ in summer and from $10{ }^{\circ} \mathrm{C}$ to $18{ }^{\circ} \mathrm{C}$ in winter. Rice flooding occurs via irrigation channels and the water comes from the local river, the Aranguará, and from streams. This region covers 9,500 ha of rice grown by at least 320 families and it is characterized by prolonged flooding in the growing areas. During the inter-crop season, the soils with poor natural drainage remain flooded during the winter, where some weeds such as swamp rice grass, Leersia hexandra Sw. contribute to the maintenance or proliferation of nematode populations during this season. In Argentina (Tucumã), M. ottersoni was detected on barnyard grass, Echinocloa crus-galli (L.) P. Beauv. by Doucet and Pinochet (1992) using only the typical perineal-pattern described by Thorne (1969) and Jepson (1987). Our results confirm the correct identification of $M$. ottersoni by these authors, considering that E. crus-galli was also a good host for the Brazilian population of this RKN. 
Fig. 7 Maximum Likelihood analysis of the phylogenetic relationships of Meloidogyne ottersoni (M. sp.0) and other Meloidogyne spp. populations based on the D2-D3 fragment of 28S rRNA sequences. Numbers to the left of the branches are bootstrap values for 1,000 replications. Accession numbers from GenBank are listed before the species names

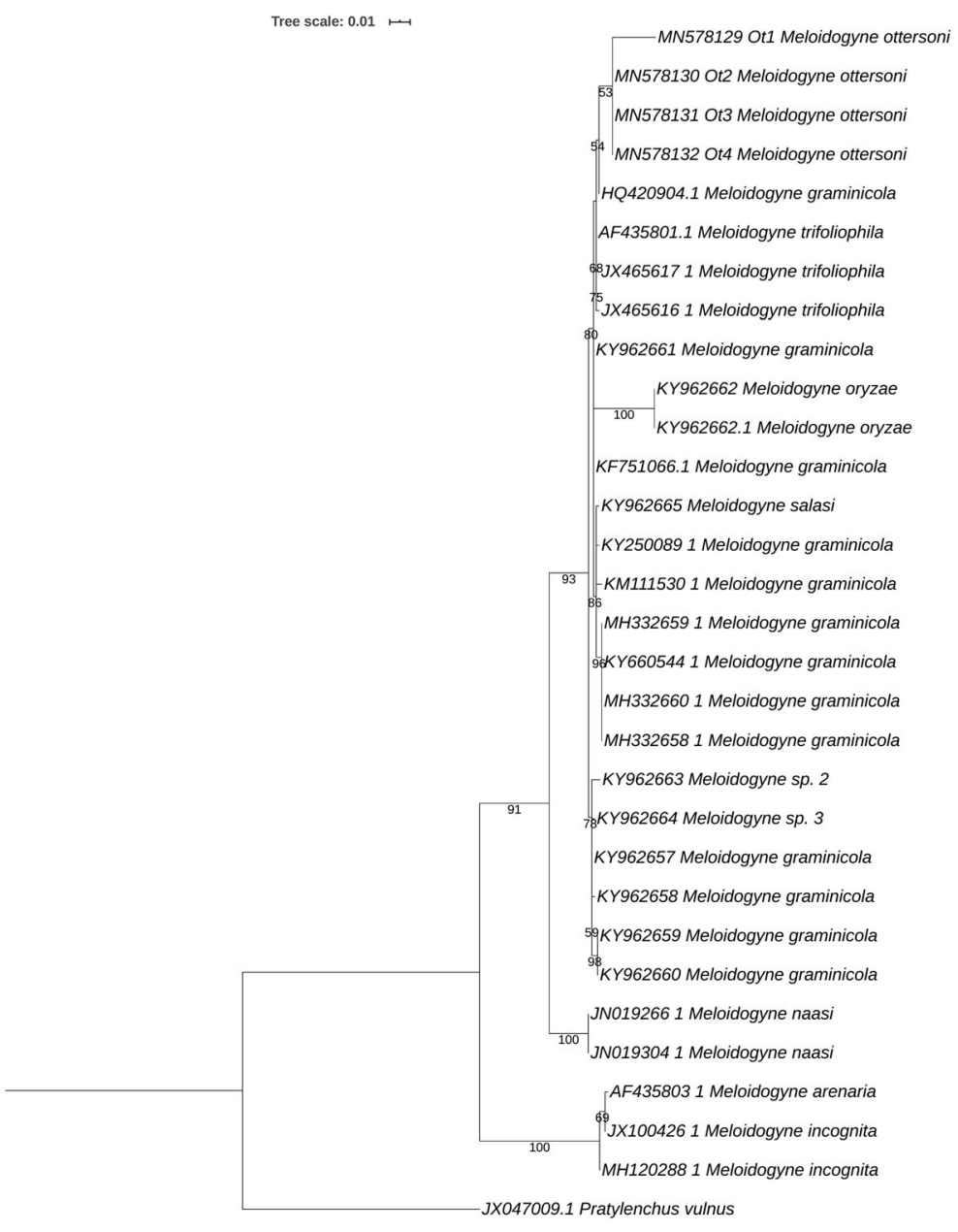

Tail morphology of the second-stage juvenile of M. ottersoni places it in Jepson's Group 11 (Jepson 1987). This is the most well defined group within the genus Meloidogyne, which now includes 10 species that parasitize rice and present differential hyaline tail length: M. graminicola $(17.9 \mu \mathrm{m})$, M. graminis (Sledge

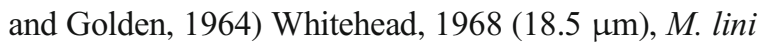
Yang, $\mathrm{Hu}$ and $\mathrm{Xu}, 1988(\sim 14.0 \mu \mathrm{m})$, M. hainanensis Liao and Feng, 1995 ( 15.3 $\mu \mathrm{m})$, M. salasi $(19.7 \mu \mathrm{m})$, M. triticoryzae Gaur, Saha and Khan, 1993 (17.6 $\mu \mathrm{m})$, M. marylandi Jepson and Golden, 1987 (11.8 $\mu \mathrm{m})$, M. sasseri Handoo, Huettel and Golden, 1995 (19.5 $\mu \mathrm{m})$, M. oryzae $(22.0 \mu \mathrm{m})$ (Mattos et al. 2018), and finally M. ottersoni $(20.5 \mu \mathrm{m})$.

Most Meloidogyne species from rice (Group 11) have been poorly described, as well as poorly characterized cytogenetically, enzymatically and molecularly. Some morphological and biological characters are common in these species: female body elongated, vulva sometimes situated on a posterior protuberance, association with an amphimictic or parthenogenetic mode of reproduction, semi-endoparasitism, with males abundant and females deeply embedded in the host (Jepson 1987). One exception is $M$. oryzae, which reproduces by mitotic parthenogenesis and presents few males (Mattos et al. 2018).

In Thorne's (1969) description of $M$. ottersoni, a very small number of specimens were obtained and measured: females (10), males (7) and J2 (10), directly picked up from roots of reed canary grass collected in the field. In our situation, the populations of $M$. ottersoni were multiplied on rice under greenhouse conditions for three months. In general, the morphology and morphometric data of $M$. ottersoni populations from Brazil were similar to the original description (Thorne 1969; Jepson 1987), with expected variations frequent for the genus Meloidogyne. The populations from Brazil had bigger female, male and J2 compared to the type population from US. This variation in body length can occur in 
Tree scale: $0.01 \mathrm{H}$

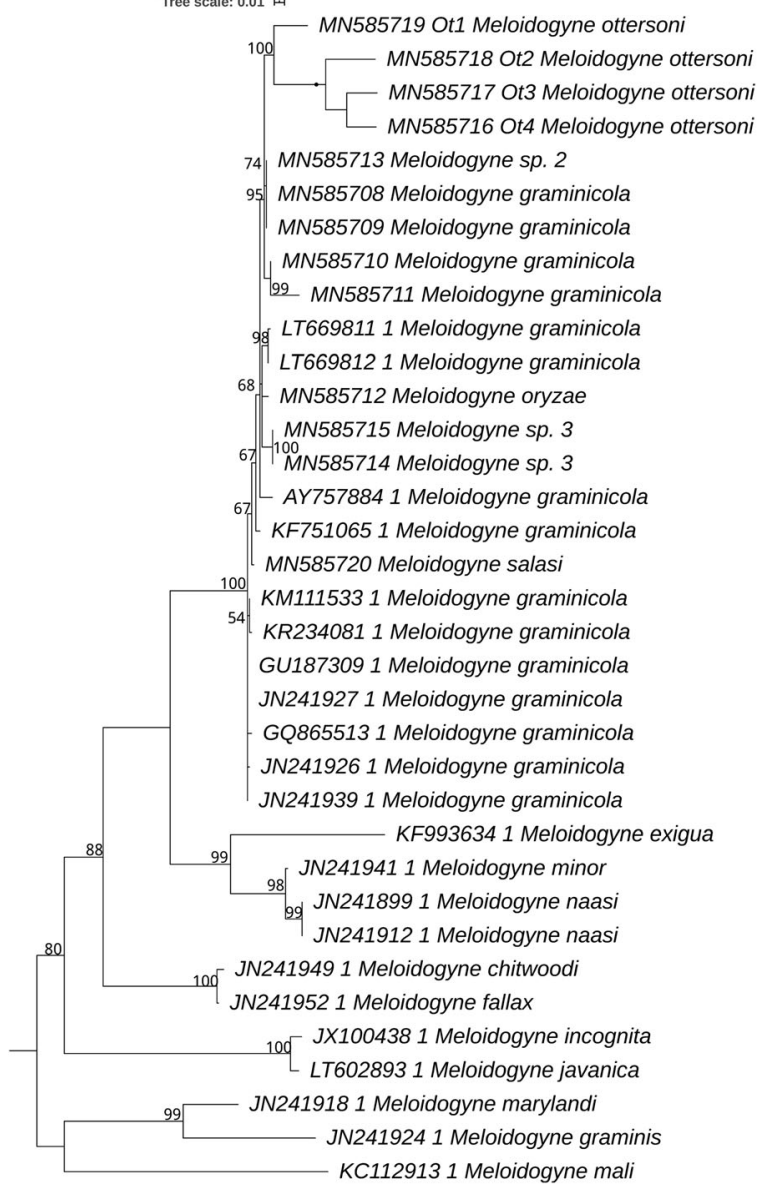

Fig. 8 Maximum Likelihood analysis of the phylogenetic relationships of Meloidogyne ottersoni (M. sp.0) and other Meloidogyne spp. populations based on the COXII-16S rRNA sequences. Numbers to the left of the branches are bootstrap values for 1,000 replications. Accession numbers from GenBank are listed before the species names populations of the same species (Handoo et al. 1993). The stylets of females and males were similar in length, but the population from the USA presented J2 with longer stylet. Some authors consider morphological features much more relevant in species characterization than morphometric characters (Jepson 1987; Eisenback and Triantaphyllou 1991). Considering these aspects, M. ottersoni populations collected in Brazil were very close to the described population from the USA and parasitize the same type host plant Phalaris arundinaceae, corroborating Koch's postulates. Considering the narrow range of hosts registered for M. ottersoni, some botanical species could be used in crop rotation with rice: soybean, black and white oats, ryegrass and barley, among others presented in Table 3. Further studies are needed to confirm our results, including more crops and varieties.

Biochemically, M. ottersoni, M. graminicola and M. oryzae showed distinct esterase profiles; the first one without bands $(\mathrm{Rm}=0)$, and the others with drawnout bands in different positions (Esbenshade and Triantaphyllou 1985; Mattos et al. 2018). This phenotype has never been clearly characterized before and seems to be a new and a species-specific character for M. ottersoni. A similar phenomenon occurs with Meloidogyne exigua Göldi, 1987: more than 10 females are required to reveal esterases satisfactorily (Carneiro et al. 2000). This is due to the reduced size of females and low concentration of the esterase enzyme. For M. ottersoni, even though more than 20 females per individual analysis were used in this study, no esterase band was observed. However, to use this criterion as a diagnostic character, it is necessary to reveal another enzymatic activity with the same extract, to ensure that

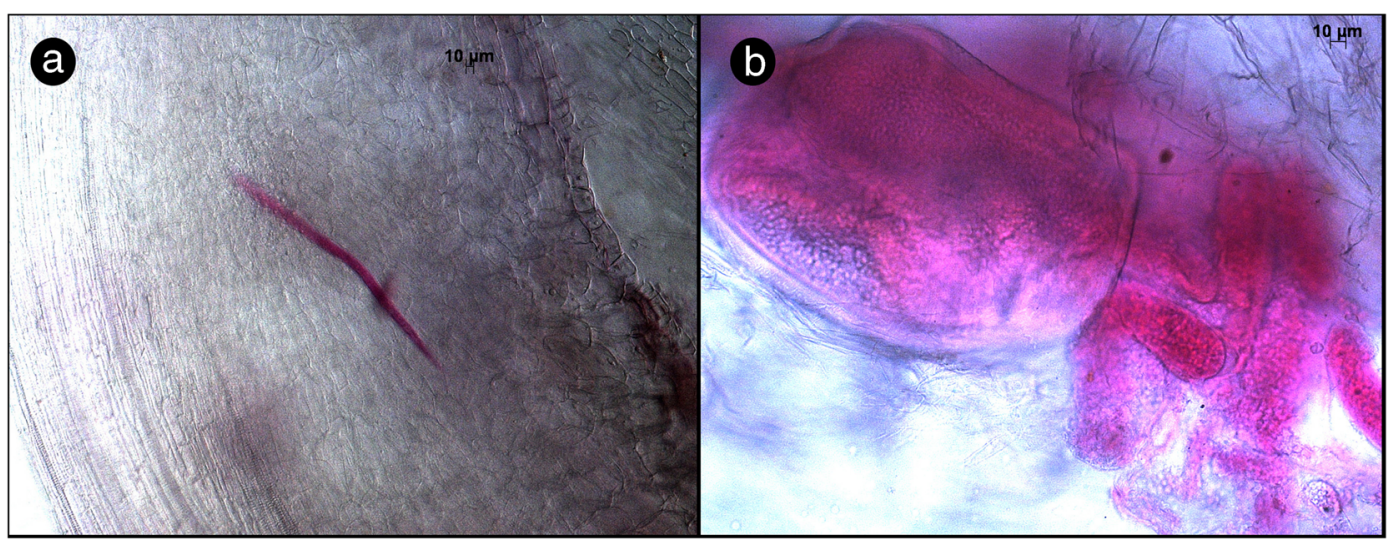

Fig. 9. Photomicrographs of Meloidogyne ottersoni parasitizing reed canary grass, Phalaris arundinacea. a: second-stage juveniles inside the root; $\mathbf{b}$ : female and eggs inside the roots 
Table 3 Host status of different botanic species inoculated with Meloidogyne ottersoni

\begin{tabular}{|c|c|c|c|c|c|}
\hline Botanic species & Root weight ${ }^{*}$ & Total eggs ${ }^{*}$ & Eggs/g root ${ }^{*}$ & $\mathrm{RF}$ & Status \\
\hline $\begin{array}{l}\text { Rice } \\
\text { Oryza sativa L. } \\
\text { Var. IRGA } 424\end{array}$ & $50.00 \mathrm{~b}$ & $2389200 \mathrm{a}$ & $8283.26 \mathrm{~b}$ & $238.92 \mathrm{a}$ & Good-host \\
\hline $\begin{array}{l}\text { Wheat } \\
\text { Triticum cestivum } \mathrm{L} \text {. } \\
\text { Var. Torsik }\end{array}$ & $5.20 \mathrm{~d}$ & $1353 \mathrm{~b}$ & $314.04 \mathrm{c}$ & $0.14 \mathrm{~b}$ & Non-host \\
\hline $\begin{array}{l}\text { Wheat } \\
\text { Triticum cestivum L. } \\
\text { Var. Sonik }\end{array}$ & $2.40 \mathrm{e}$ & $773 \mathrm{~b}$ & $410.67 \mathrm{c}$ & $0.08 \mathrm{~b}$ & Non-host \\
\hline $\begin{array}{l}\text { Signalgrass } \\
\text { Brachiaria decumbens Stapf } \\
\text { Unknown variety }\end{array}$ & $41.80 \mathrm{~b}$ & $807 \mathrm{~b}$ & $21.12 \mathrm{~d}$ & $0.08 \mathrm{~b}$ & Non-host \\
\hline $\begin{array}{l}\text { Cowpea } \\
\text { Vigna unguiculata L. Walp } \\
\text { Unknown variety }\end{array}$ & $6.88 \mathrm{~d}$ & $900 \mathrm{~b}$ & $122.14 \mathrm{~d}$ & $0.09 \mathrm{~b}$ & Non-host \\
\hline $\begin{array}{l}\text { Black Oat } \\
\text { Avena strigosa Schreb } \\
\text { Unknown variety }\end{array}$ & $17.80 \mathrm{c}$ & $1080 \mathrm{~b}$ & $60.09 \mathrm{~d}$ & $0.11 \mathrm{~b}$ & Non-host \\
\hline $\begin{array}{l}\text { White Oat } \\
\text { Avena sativa } \mathrm{L} . \\
\text { Var. Estampa }\end{array}$ & $6.40 \mathrm{~d}$ & $59020 \mathrm{~b}$ & $4245.67 \mathrm{c}$ & $5.90 \mathrm{~b}$ & Bad-host \\
\hline $\begin{array}{l}\text { Tomato } \\
\text { Solanum licopersycum L. } \\
\text { Var. Santa Clara }\end{array}$ & $55.75 \mathrm{~b}$ & $2417 \mathrm{~b}$ & $48.57 \mathrm{~d}$ & $0.24 \mathrm{~b}$ & Non-host \\
\hline $\begin{array}{l}\text { Pearl Millet } \\
\text { Pennisetum glaucun L. } \\
\text { Var. ADR905 }\end{array}$ & $144.40 \mathrm{a}$ & $3467 \mathrm{~b}$ & $21.94 \mathrm{~d}$ & $0.35 \mathrm{~b}$ & Non-host \\
\hline $\begin{array}{l}\text { Pearl Millet } \\
\text { Pennisetum glaucun } \\
\text { Var. ADR500 }\end{array}$ & $160.70 \mathrm{a}$ & $3467 \mathrm{~b}$ & $20.38 \mathrm{~d}$ & $0.35 \mathrm{~b}$ & Non-host \\
\hline $\begin{array}{l}\text { Italian Ryegrass } \\
\text { Lolium multiflorum Lam } \\
\text { Unknown variety }\end{array}$ & $21.80 \mathrm{c}$ & $4207 \mathrm{~b}$ & $189.08 \mathrm{c}$ & $0.42 \mathrm{~b}$ & Non-host \\
\hline $\begin{array}{l}\text { Soybean } \\
\text { Glycine } \max (\text { L.) Mer. } \\
\text { Var. Potência }\end{array}$ & $16.67 \mathrm{c}$ & $4778 \mathrm{~b}$ & $326.79 \mathrm{c}$ & $0.48 \mathrm{~b}$ & Non-host \\
\hline $\begin{array}{l}\text { Soybean } \\
\text { Glycine max } \\
\text { Var. Vini M8210 }\end{array}$ & $8.50 \mathrm{~d}$ & $350 \mathrm{~b}$ & $53.13 \mathrm{~d}$ & $0.04 \mathrm{~b}$ & Non-host \\
\hline $\begin{array}{l}\text { Barley } \\
\text { Hordeum vulgare L. } \\
\text { Unknown variety }\end{array}$ & $33.30 \mathrm{c}$ & $6180 \mathrm{~b}$ & $519.71 \mathrm{c}$ & $0.62 \mathrm{~b}$ & Non-host \\
\hline $\begin{array}{l}\text { Corn } \\
\text { Zea mays L. } \\
\text { IPR164 }\end{array}$ & $104.80 \mathrm{a}$ & $26000 \mathrm{~b}$ & $270.12 \mathrm{~d}$ & $2.60 \mathrm{~b}$ & Bad-host \\
\hline $\begin{array}{l}\text { Guinea grass } \\
\text { Panicum maximum Jacq } \\
\text { Unknown variety }\end{array}$ & $31.30 \mathrm{~b}$ & $17400 \mathrm{~b}$ & $590.80 \mathrm{c}$ & $1.74 \mathrm{~b}$ & Bad-host \\
\hline $\begin{array}{l}\text { Barnyardgrass } \\
\text { Echinocloa crus-galli (L.) P. Beauv } \\
\text { Var. crus - galli }\end{array}$ & $8.88 \mathrm{~d}$ & $615567 \mathrm{a}$ & $56311.50 \mathrm{a}$ & $61.56 \mathrm{a}$ & Good-host \\
\hline $\begin{array}{l}\text { Jungle rice } \\
\text { Echinocloa colonum (L.) Link } \\
\text { Unknown variety }\end{array}$ & $17.00 \mathrm{c}$ & 1107667 a & $62383.97 \mathrm{a}$ & $110.77 \mathrm{a}$ & Good-host \\
\hline $\begin{array}{l}\text { Canary grass } \\
\text { Phalaris canariensis L. }\end{array}$ & $86.50 \mathrm{a}$ & $813933.33 \mathrm{a}$ & $9547.64 \mathrm{~b}$ & $81.39 \mathrm{a}$ & Good-host \\
\hline
\end{tabular}

Var. Canadian 
Table 3 (continued)

\begin{tabular}{llllll}
\hline Botanic species & Root weight $^{*}$ & Total eggs $^{*}$ & Eggs/g root & RF & Status \\
\hline CV\% & 13.73 & 28.92 & 31.83 & 32.59 & -
\end{tabular}

*Values $(\mathrm{n}=8)$ of Reproduction Factors ( $\mathrm{RF}=$ final population/ 10000 eggs) were transformed as $\log (\mathrm{x}+1)$. Means followed by different letters in the column are significantly different according to Scott-Knott's test $(P<0.5)$

the lack of esterase activity is not due to protein degradation within the sample.

Oogenesis and spermatogenesis of the population of M. ottersoni from Wiconsin, USA were of the meiotic type $(\mathrm{n}=18)$. When males were abundant, reproduction was by amphimixis. Considering the cytogenetic studies, M. ottersoni is closely related to $M$. graminicola, M. graminis and M. naasi (Triantaphyllou 1973). The population of $M$. ottersoni from Meleiro studied in this work reproduced by meiotic parthenogenesis and presented 18 chromosomes, being similar to the M. ottersoni type population and M. graminicola and completely different from $M$. oryzae (3n=50-56 chromosomes) (Esbenshade \& Tryantaphyllou, 1985).

The multi-copy basis of rDNA provides a sample target for PCR amplification and it allows the intraspecific variation to be detected in Meloidogyne spp. populations (Zijlstra et al. 1995; Adam et al. 2007). Similar to $M$. ottersoni, the presence of intraspecific variability in rDNA sequences was reported for $M$. graminicola (Pokharel et al. 2007) and M. oryzae (Mattos et al. 2018; Besnard et al. 2019), two other RKN rice-related species.

From the perspective of identification, the mitochondrial genome provides a rich source of genetic markers for identification (Rubinoff and Holland 2005; Hu and Gasser 2006). This region has a faster rate of evolution than the corresponding nuclear genes (Hugall et al. 1994; Blok and Powers 2009). In fact, the mitochondrial coding region is already considered a better potential barcode region for some Meloidogyne spp. groups, since intergenic regions have been shown to contain AT repeats that appear not to correlate with speciation events (Hugall et al. 1997; Pagan et al. 2015). Meloidogyne ottersoni presents a unique COII sequence with low intraspecific variability, which can be useful for species identification and for phylogenetic studies.

Our results illustrated the interest of using integrative taxonomy for accurate species identification and redescription (Padial et al. 2010; Pante et al. 2015; Mattos et al. 2018). Detailed morphological, morphometrical, cytological and molecular studies allowed the clarification of the taxonomic position of M. ottersoni from rice fields. To plan efficient management of this new RKN, precise characterization and identification of nematode species is important, considering that $M$. ottersoni is completely different from $M$. graminicola, the rice RKN. The occurrence of Meloidogyne ottersoni pest was notified to the Ministry of Agriculture of Brazil (MAPA-SDA) on May 19, 2020 through the annex: form for notification of exotic pest occurrence in Brazil, through an email sent to Mr. Tiago Lohmann.

Acknowledgments This work was supported by National Council for Scientific an Technological Development (CNPq), Embrapa Genetic Resources and Biotecnology, and Research Foundation of the Federal District (FAPDF). R.R. Leite and R.M.D.G. Carneiro thank CNPq and Coordination of Improvement of Higher Education (CAPES) for their scholarships and the assistant technician Ingrid Gracielle Martins da Silva for the electron microscopy photos and the Microanalysis Laboratory of the Institute of Biological Sciences of the University of Brasilia (LMM-UnB).

Funding information Funding provided by National Council for Scientific and Technological Development (CNPq), Embrapa Genetic Resources and Biotechnology and Research Foundation of the Federal District (FAPDF). Grant numbers:193.001.167/2015

\section{Compliance with ethical standards}

Conflict of interest The authors declare that they have no conflict of interest.

Human participants and/or animals Not applicable.

Informed consent Not applicable.

\section{References}

Adam, M. A. M., Phillips, M. S., \& Blok, V. C. (2007). Molecular diagnostic key for identification of single juveniles of seven common and economically important species of root-knot nematode (Meloidogyne spp.). Plant Pathology, 56(1), 190-197. 
Bellafiore, S., Jougla, C., Chapuis, É., Besnard, G., Suong, M., $\mathrm{Vu}, \mathrm{P}$. N., et al. (2015). Intraspecific variability of the facultative meiotic parthenogenetic root-knot nematode (Meloidogyne graminicola) from rice fields in Vietnam. Comptes Rendus Biologies, 338(7), 471-483.

Bernard, E. C., \& Eisenback, J. D. (1997). Meloidogyne trifoliophila n.sp. (Nemata: Meloidogynidae), a parasite of clover from Tennessee. Journal of Nematology, 29(1), 4354.

Besnard, G., Thi-Phan, N., Ho-Bich, H., Dereeper, A., Trang Nguyen, H., Quénéhervé, P., \& Bellafiore, S. (2019). On the close relatedness of two rice-parasitic root-knot nematode species and the recent expansion of Meloidogyne graminicola in Southeast Asia. Genes, 10(2), 175.

Blok, V. C., \& Powers, T. O. (2009). Biochemical and molecular identification. In R. N. Perry, M. Moens, \& J. L. Starr (Eds.), Root-knot nematodes Wallingford (pp. 98-118). UK: CABI.

Byrd Jr., D. W., Kirkpatrick, T., \& Barker, K. R. (1983). An improved technique for clearing and staining plant tissues for detection of nematodes. Journal of Nematology, 15(1), 142.

Carneiro, R. M. D. G., \& Almeida, M. R. A. (2001). Técnica de eletroforese usada no estudo de enzimas dos nematoides de galhas para identificação de espécies. Nematologia Brasileira, 25(1), 35-44.

Carneiro, R. M. D. G., Castagnone-Sereno, P., \& Dickson, D. W. (1998). Variability among four populations of Meloidogyne javanica from Brazil. Fundamental and Applied Nematology, 4(21), 319-326.

Carneiro, R. M. D. G., Almeida, M. R. A., \& Quénéhervé, P. (2000). Enzyme phenotypes of Meloidogyne spp. populations. Nematology, 2(6), 645-654.

Chauhan, B. S., Jabran, K., \& Mahajan, G. (2017). Rice Production Worldwide. In R. Prasad, Y. S. Shivay, \& D. Kumar (Eds.), Current status, challenges, and opportunities in rice production (pp. 1-15) Springer Nature.

Conab-Companhia Nacional de Abastecimento. Acompanhamento da Safra Brasileira de Grãos (2018), 7(5), 51-60.

De Ley, P., Felix, M. A., Frisse, L. M., Nadler, S. A., Stember, P. W., \& Thomas, W. K. (1999). Molecular and morphological characterisation of two reproductive species with mirror image anatomy (Nematoda: Cephalobidae). Nematology, 1(6), 591-612.

De Waele, D., \& Elsen, A. (2007). Challenges in tropical plant nematology. Annual Review of Phytopathology, 45(1), 457485.

Doucet, M. E., \& Pinochet, J. (1992). Occurrence of Meloidogyne spp. in Argentina. Supplement to Journal of Nematology, 24(4S), 765-770.

Eisenback, J. D. (1985). Techniques for preparing nematodes for scanning electron microscopy. An advanced treatise on Meloidogyne, 2, 79-105.

Eisenback, J. D., \& Hunt, D. J. (2009). General morphology. In R. N. Perry, M. Moens, \& J. L. Starr (Eds.), Root-knot nematodes (pp. 18-54). Wallingford, UK: CABI.

Eisenback, J. D., \& Triantaphyllou, H. H. (1991). Root-Knot nematode: Meloidogyne spp. and races. In W. R. Nickle (Ed.), Manual of Agricultural Nematology (pp. 191-274). New York: Macel Deccker, Inc..
Esbenshade, P. R., \& Triantaphyllou, A. C. (1985). Use of enzyme phenotypes for identification of Meloidogyne species (Nematoda: Tylenchida). Journal of Nematology, 17(1), 620.

Franklin, M. T. (1971). Taxonomy of Heteroderidae. In: Zuckerman, B.M., Mai, W.F. and Rohde, R.A. (eds.). Plant Parasitic Nematodes, vol II. Academic Press, New York, pp. 139-162.

Handoo, Z. A., Huettel, R. N., \& Golden, A. M. (1993). Description and SEM observations of Meloidogyne sasseri n.sp. (Nematoda: Meloidogynidae), parasitizing beachgrasses. Journal of Nematology, 25(4), 628.

Htay, C., Peng, H., Huang, W., Kong, L., He, W., Holgado, R., \& Peng, D. (2016). The development and molecular characterization of a rapid detection method for rice root-knot nematode (Meloidogyne graminicola). European Journal of Plant Pathology, 146(2), 281-291.

Hu, M. \& Gasser, R. B. (2006). Mitochondrial genomes of parasitic nematodes - progress and perspectives. Trends in Parasitology, 22(2), 78-84

Hugall, A., Moritz, C., Stanton, J., \& Wolstenholme, D. R. (1994). Low, but strongly structured mitochondrial DNA diversity in root knot nematodes (Meloidogyne). Genetics, 136(3), 903912.

Hugall, A., Stanton, J., \& Moritz, C. (1997). Evolution of the ATrich mitochondrial DNA of the root knot nematode, Meloidogyne hapla. Molecular Biology and Evolution, 14(1), 40-48.

Hunt, D. J., \& Handoo, Z. A. (2009). Taxonomy, identification and principal species. In R. N. Perry, M. Moens, \& J. L. Starr (Eds.), Root-knot nematodes (pp. 55-97). Wallingford: CABI.

Hussey, R. S., \& Barker, K. R. A. (1973). Comparision of methods of collecting inocula of Meloidogyne spp. including a new technique. Plant Disease Reporter, 57(12), 1025-1028.

Jepson, S. B. (1987). Identification of root-knot nematodes (Meloidogyne species). Wallingford: CABI.

Karssen, G., \& Moens, M. (2006). Root-knot nematodes Plant Nematology. Wallingford, UK, CABI Publishing.pp. 59-90.

Khan, M. R. (2015). Nematode diseases of crop in India. In L. P. Awasthi (Ed.), Recent advances in the diagnosis and managament of plant diseases (pp. 183-224). New Delhi.pp: Springer.

Mattos, V. S., Soares, M. R. C., Gomes, A. C. M. M., Arieira, C. R. D., Gomes, C. B., \& Carneiro, R. M. D. G. (2017). Caracterização de um complexo de espécies do nematoide das galhas parasitando arroz irrigado na região sul do Brasil. In Boletim de Pesquisa e Desenvolvimento 331 (28p). Embrapa Recursos: Genéticos e Biotecnoloiga.

Mattos, V. S., Cares, J. E., Gomes, C. B., Gomes, A. C. M. M., Monteiro, J. D. M. S., Gomez, G. M., Castagnone-Sereno, P., \& Carneiro, R. M. D. G. (2018). Integrative Taxonomy of Meloidogyne oryzae (Nematoda: Meloidogyninae) parasitizing rice crops in Southern Brazil. European Jounal of Plant Pathology, 151(3), 649-662.

McClure, M. A., Nischwitz, C., Skantar, A. M., Schmitt, M. E., \& Subbotin, S. A. (2012). Root-knot nematodes in golf course greens of the western United States. Plant Disease, 96(5), 635-647.

Moens, M., Perry, R. N., \& Starr, J. L. (2009). Meloidogyne species - a diverse group of novel and important plant 
parasites. In R. N. Perry, M. Moens, \& J. L. Starr (Eds.), Root knot nematodes Wallingford (pp. 1-17). UK: CABI.

Negretti, R. R., Gomes, C. B., Mattos, V. S., Somavilla, L., Manica-Berto, R., Agostinetto, D., Castagnone-Sereno, P., \& Carneiro, R. M. D. G. (2017). Characterisation of a Meloidogyne species complex parasitising rice in southern Brazil. Nematology, 19(4), 403-412.

Nylander, J. A. A. (2004). MrModelTest, version 2 Evolutionary Biology Centre. Uppsala University.

Padial, J. M., Miralles, A., De La Riva, I., \& Vences, M. (2010). The integrative future of taxonomy. Frontiers in Zoology, $7(1), 16$.

Pagan, C., Coyne, D., Carneiro, R., Kariuki, G., Luambano, N., Affokpon, A., \& Williamson, V. M. (2015). Mitochondrial haplotype-based identification of ethanol-preserved rootknot nematodes from Africa. Phytopathology, 105(3), 350357.

Pante, E., Abdelkrim, J., Viricel, A., Gey, D., France, S. C., Boisselier, M. C., \& Samadi, S. (2015). Use of RAD sequencing for delimiting species. Heredity, 114(5), 450.

Pokharel, R. R., Abawi, G. S., Zhang, N., Duxbury, J. M., \& Smart, C. D. (2007). Characterization of isolates of Meloidogyne from rice-wheat production fields in Nepal. Journal of Nematology, 39(3), 221.

Pokharel, R. R., Abawi, G. S., Duxbury, J. M., Smat, C. D., Wang, X., \& Brito, J. A. (2010). Variability and the recognition of two races in Meloidogyne graminicola. Australasian Plant Pathology, 39(4), 326-333.

Powers, T. O., \& Harris, T. S. (1993). A polymerase chain reaction method for identification of five major Meloidogyne species. Journal of Nematology, 25(1), 1-6.

Rubinoff, D., \& Holland, B. S. (2005). Between two extremes: mitochondrial DNA is neither the panacea nor the nemesis of phylogenetic and taxonomic inference. Systematic Biology, 54(6), 952-961.

Salalia, R., Walia, R. N., Somvanshi, V. S., Kumar, P., \& Kumar, A. (2017). Morphological, morphometric and molecular characterization of intraspecific variation within Indian populations of Meloidogyne graminicola. Journal of Nematology, 49(3), 254-267.

Schmitz, B., Burgermeister, W., \& Braasch, H. (1998). Molecular genetic classification of Central European Meloidogyne chitwoodi and M. fallax populations. Nachrichtenblatt des Deutschen Pflanzenschutzdienstes, 50(12), 310-317.

Subbotin, S., Waeyenberge, A. L., \& Moens, M. (2000). Identification of cyst forming nematodes of the genus Heterodera (Nematoda: Heteroderidae) based on the ribosomal DNA RFLPs. Nematology, 2(2), 153-164.

Tamura, K., Peterson, D., Peterson, N., Stecher, G., Nei, M., \& Kumar, S. (2011). MEGA5: molecular evolutionary genetics analysis using maximum likelihood, evolutionary distance, and maximum parsimony methods. Molecular Biology and Evolution, 28(10), 2731-2739.

Taylor, D. P., \& Netscher, C. (1974). An improved technique for preparing perineal patterns of Meloidogyne spp. Nematologica, 20(2), 268-269.

Thorne, G. (1969). Hypsoperine ottersoni sp. n. (Nemata, Heteroderidae) infesting Canary grass, Phalaris arundinacea (L.) reed in Wisconsin. Proceedings of the Helminthological Society of Washington, 36, 98-102.

Triantaphyllou, A. C. (1973). Gametogenesis and reproduction of Meloidogyne graminis and M. ottersoni (Nematoda: Heteroderidae). Journal of Nematology, 5(2), 84.

Triantaphyllou, A. C. (1985). Cytological methods for the study of oogenesis and reproduction of root-knot nematodes. In K. R. Barker, C. C. Carter, \& J. N. Sasser (Eds.), An advanced treatise on Meloidogyne: Methodology (Vol. 2, pp. 107114). Raleigh: North Carolina State University Graphics.

Trifinopoulos, J., Nguyen, L. T., von Haeseler, A., \& Minh, B. Q. (2016). W-IQ-TREE: a fast online phylogenetic tool for maximum likelihood analysis. Nucleic Acids Research, 44(W1), W232-W235.

Zijlstra, C., Lever, A. E. M., Uenk, B. J., \& van Silfhout, C. H. Y. (1995). Differences between ITS regions of isolates of rootknot nematodes Meloidogyne hapla and M. chitwoodi. Phytopathology, 85(10), 1231-1237. 